\title{
NKX2-5 wt Allele
}

National Cancer Institute

\section{Source}

National Cancer Institute. NKX2-5 wt Allele. NCI Thesaurus. Code C102511.

Human NKX2-5 wild-type allele is located in the vicinity of $5 q 34$ and is approximately $3 \mathrm{~kb}$ in length. This allele, which encodes homeobox protein Nkx-2.5, is involved in both heart development and the modulation of transcription. Mutation of the gene is associated with atrial septal defect type 7, tetralogy of Fallot, and congenital hypothyroidism nongoitrous type 5 . 